\title{
Potential environmental risks associated with biofouling management in salmon aquaculture
}

\author{
Oliver Floerl ${ }^{1,2, *}$, Leif Magne Sunde ${ }^{1}$, Nina Bloecher ${ }^{1}$ \\ ${ }^{1}$ SINTEF Fisheries and Aquaculture, 7010 Trondheim, Norway \\ ${ }^{2}$ Present address: Cawthron Institute, Nelson 7010, New Zealand
}

\begin{abstract}
The accumulation of biofouling organisms on farm infrastructure is an on-going problem for the global salmon aquaculture industry. Most salmon farmers in production regions worldwide undertake regular in situ net cleaning using specialised high-pressure washing rigs. Generally, the material removed from the net during cleaning is discharged into the surrounding environment. This 'cleaning waste' consists predominantly of biofouling organisms (intact and fragmented), but may also contain fish pathogens and antifouling coating particles containing biocides. The suspension, dispersal and deposition of this material are associated with a range of potential risks that can be grouped into 4 main categories: (1) health or disease risks (e.g. direct damage to sensitive tissues upon contact with cleaning waste, and facilitation of infection by pathogens); (2) deposition and pollution risks (impact on benthic communities around farms through deposition of organic material and antifouling biocides); (3) invasive species risks (localised dispersal of non-indigenous propagules and fragments); and (4) biofouling exacerbation (e.g. 'self-seeding' of downstream production cages). Here, we describe and discuss these 4 potential risks associated with in situ cleaning and present an agenda and research priorities to better understand and manage these risks.
\end{abstract}

KEY WORDS: Aquaculture $\cdot$ Net cleaning $\cdot$ Biofouling $\cdot$ Fish farming $\cdot$ Salmo salar $\cdot$ Nematocysts $\cdot$ Farm management

\section{BIOFOULING IN SALMON AQUACULTURE: SCALE AND MANAGEMENT}

The accumulation of biofouling organisms on submerged marine farming infrastructure or culture stock is an on-going problem for the global aquaculture industry (Braithwaite \& McEvoy 2005, Fitridge et al. 2012). In finfish farms, diverse biofouling assemblages comprising most marine phyla develop on net pens and the submerged parts of associated structures such as floating collars, mooring systems and feed barges (Greene \& Grizzle 2007, Rensel \& Forster 2007, Atalah et al. 2013, Bloecher et al. 2015).

\footnotetext{
*Corresponding author: oliver.floerl@cawthron.org.nz
}

Studies from a range of global salmon-growing regions have reported biofouling organisms covering $>60 \%$ of the surface area of farm nets, with net occlusion of up to $100 \%$ (Cronin et al. 1999, Braithwaite et al. 2007, Guenther et al. 2010, B. Yaxley, Petuna Aquaculture, unpubl. data). In Norway, biofouling on $50 \mathrm{~m}$ diameter pens can reach a biomass of 2 to $7 \mathrm{t}$ (Bloecher 2013). Biofouling can cause deformation and volume reduction of net pens, increase mooring loads due to higher current resistance and can lead to structural fatigue. It can affect fish welfare by reducing oxygen levels, waste removal and the effectiveness of cleaner fish in sea lice control (Kvenseth 1996,

() The authors 2016. Open Access under Creative Commons by Attribution Licence. Use, distribution and reproduction are unrestricted. Authors and original publication must be credited. 
Lader et al. 2008, Fitridge et al. 2012) (Fig. 1). Biocidal antifouling coatings for production nets are used widely (Guardiola et al. 2012), but not in all growing regions (e.g. not in New Zealand and parts of Canada; J. Atalah, Cawthron Institute, pers. comm.; D. Morrison, Marine Harves, pers. comm.). Where they are used, they are often of limited effectiveness as they do not provide long-term protection (Braithwaite et al. 2007, Guenther et al. 2011).

To avoid the impacts associated with biofouling development, salmon farmers in most global growing regions (including Norway, the UK, Canada, Chile, Australia and New Zealand) undertake regular in situ net cleaning (Guenther et al. 2010, Baxter et al. 2012, Atalah et al. 2013, K. Page, MIC Marine; J. Unibazo, AVS; D. Morrison, Marine Harvest; B. House, Atlantic Canada Fish Farmers Association, pers. comm.). Although a range of other methods have been employed in smaller-scale salmon farms (including air-drying or exchanging fouled nets), in situ cleaning has become the default method for biofouling management in larger commercial farms (Olafsen 2006). In Norway's $\sim 700$ active salmon farms (Norway Directorate of Fisheries pers. comm.), net cleaning is generally undertaken using specialised high-pressure cleaning rigs whose rotating discs deliver water jets with a cleaning pressure of 200 to 400 bar (20-40 MPa). Cleaning rigs vary in size; large models can achieve a cleaning path $\sim 3 \mathrm{~m}$ in width. The rigs are generally operated from an attending support vessel and conduct vertical cleaning transects around the perimeter of the pens,

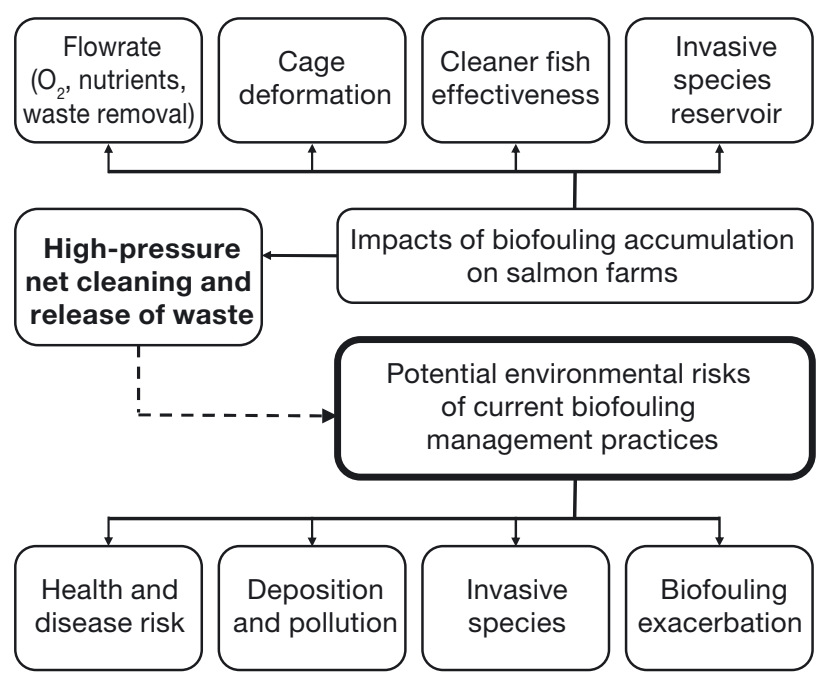

Fig. 1. In situ high pressure net cleaning is carried out to reduce the impacts of biofouling accumulation on salmon farm nets. However, this practice is associated with several potential environmental risks although some newer models are self-propelled and able to move around in all directions. Similar technology, including diver-operated cleaning rigs, is used in other salmon growing regions. The water jets emitted by the cleaning rigs dislodge biofouling organisms from the nets. In most operations, material removed from nets during cleaning is not collected and instead discharged into the surrounding environment. This 'cleaning waste' consists predominantly of biofouling organisms (Carl et al. 2011), but is also likely to contain fragments of antifouling coatings where these are being used. The effect of net cleaning does not last long: in Norway, Tasmania, Japan and other growing regions, many farms operate 1- to 2-weekly cleaning cycles during the peak biofouling season (summer/autumn), while during colder months nets are cleaned every 4 to 6 wk (Olafsen 2006, Guenther et al. 2010, Fitridge et al. 2012, Bloecher et al. 2015). Up to 20 cleaning events may be required for each farm pen annually, resulting in the periodic release of a large amount of cleaning waste. The composition, fate and environmental effects of this material are currently poorly understood, and are the main subject of this article.

Ecological sustainability of aquaculture is a key goal for environmental managers and scientists, and a wealth of studies have examined the impacts of fish and shellfish farms and how they could be minimised (Hargrave 2010, Taranger et al. 2015 and references therein). In comparison, little consideration has been given to the impacts of biofouling species that colonise aquaculture farms. Some recent studies have addressed the role of biofouling organisms in shellfish aquaculture, but mainly to establish whether they compete with farmed shellfish for space, food or nutrients (LeBlanc et al. 2003, Daigle \& Herbinger 2009, Woods et al. 2012). To date, the management of biofouling organisms in finfish aquaculture, including antifouling and net cleaning activities, has in many regions been left to industry and has not everywhere received adequate regulatory scrutiny in terms of its potential consequences and effects on surrounding habitats and species. The annual cleaning waste arising from individual salmon farms is a function of local biofouling intensity and the maintenance strategy employed by the farm (net types deployed, use of antifouling coatings, net cleaning frequency). All of these factors vary geographically and between companies; however, based on available data, biofouling waste generated by individual salmon farms can be in the order of dozens of tonnes (Table 1). Given this scale of release, the continued use of biocidal antifouling coatings in some global production regions 
Table 1. Potential emissions (tonnes) of biofouling 'cleaning waste' for an average Norwegian salmon farm comprising 8 production pens (50 $\mathrm{m}$ diameter). Emitted biomass is a function of the amount of growth on individual nets and the frequency at which the nets are cleaned. Biofouling intensity varies regionally, but up to $7 \mathrm{t}$ of biofouling have been reported for individual pen nets (Bloecher 2013). Extreme fouling biomass is unlikely to accumulate in situations where cleaning occurs at short intervals; some combinations of fouling biomass and cleaning frequency are thus considered unlikely (UL). Note that the data presented here are for illustrative purposes and do not represent definite values of biomass

\begin{tabular}{|lcccc|}
\hline \multirow{2}{*}{$\begin{array}{l}\text { Biomass per net pen } \\
\text { (t wet weight) }\end{array}$} & \multicolumn{5}{c|}{ Cleaning events farm $\mathrm{fr}^{-1} \mathrm{yr}^{-1}$} \\
& 2 & 5 & 10 & 20 \\
\hline 0.25 & 4 & 10 & 20 & 40 \\
0.5 & 8 & 20 & 40 & 80 \\
1 & 16 & 40 & 80 & 160 \\
2 & 32 & 80 & 160 & (UL) \\
7 & 112 & 280 & (UL) & (UL) \\
\hline
\end{tabular}

and the existence of densely farmed areas in relatively pristine natural environments, it seems prudent to give more consideration to the potential ecological consequences of biofouling management in salmon aquaculture. In this article, we present and discuss the potential environmental risks associated with in situ cleaning of production nets in fish farms (Fig. 1) and present operational and technological avenues and research priorities for improved, ecologically sustainable biofouling management.

\section{POTENTIAL ENVIRONMENTAL RISKS OF IN SITU NET CLEANING}

Net cleaning operations in salmon farms release a range of materials into the surrounding environment, including biofouling organisms and their propagules (some of which may be viable; Carl et al. 2011), antifouling coating fragments (where treated nets are used) and biofilms and organic debris accumulated on the net and the external surfaces of biofouling organisms. The suspension, dispersal and deposition of this material can be associated with a range of potential risks that we have grouped into 4 main categories: health and disease, deposition and pollution, invasive species and biofouling exacerbation (Fig. 1).

\section{Health and disease risks}

Biofouling organisms contained in cleaning waste from net pens can pose potential health and disease risks to farmed finfish in 2 ways: (1) by causing direct damage to sensitive tissues upon contact, or (2) by facilitating exposure to infectious disease pathogens. The first type of risk (gill or skin disorder) is particularly important where biofouling communities on production pens contain cnidarian species. For example, in many of the main global salmon-growing regions biofouling communities on net pens are dominated by hydroids or sea anemones. In Norwegian and Irish Atlantic salmon farms, the hydroid Ectopleura larynx occurs at densities of up to 126000 polyps $\mathrm{m}^{-2}$ of pen nets (Guenther et al. 2010, Baxter et al. 2012, Lader et al. 2015) and its recruitment dynamics represent one of the main drivers of net cleaning operations. Densities of up to 45000 polyps $\mathrm{m}^{-2}$ have been observed for the closely related species E. exxonia on New Zealand Chinook salmon farms (Atalah et al. 2013), and hydroids of the genera Ectopleura, Plumelaria, Obelia and Sarsia are amongst the most abundant biofouling organisms on or around salmon farms in Tasmania and North America (Rensel \& Forster 2007; B. Yaxley, Petuna Aquaculture, unpubl. data). In New Zealand, the white-striped anemone Anthothoe albocincta is abundant on pen and predator nets of salmon farms where it can reach densities of 1600 ind. $\mathrm{m}^{-2}$ (Atalah et al. 2013). At least 2 further species of anemone, Viatrix (Bunodeopsis) sp. and the brown-striped anemone Diadumne (Haliplanella) sp., have been identified from New Zealand salmon farms, where they also reach considerable densities (Atalah \& Smith 2015). Also in Canada (New Brunswick and British Columbia), hydroids and anemones are among the main biofouling organisms on salmon pen nets (B. House, Atlantic Canada Fish Farmers Association; D. Morrison, Marine Harvest Canada, pers. comm.).

Like all cnidarians, hydroids and anemones possess millions of harpoon-like stinging cells (nematocysts) that contain nerve- or cardiotoxins and are used to capture and immobilise prey (Sher \& Zlotkin 2009, Frazão et al. 2012, Cegolon et al. 2013). Hydroids and anemones are relatives of the hydrozoan and scyphozoan jellyfish that have been identified as important agents of gill disorder in farmed salmon (Rodger et al. 2011). For example, even brief contact with the nematocysts of the common jellyfish Aurelia aurita has been shown to cause substantial gill damage in farmed Atlantic salmon, with the extent and severity of damage increasing for up to $48 \mathrm{~h}$ (Baxter et al. 2011).

In farms with extensive hydroid or anemone populations, large quantities (in some cases tonnes) of nematocyst-bearing material may be released during the cleaning of individual pens, resulting in a situa- 
tion somewhat similar to a jellyfish bloom. In a Norwegian salmon farm, for example, concentrations of up to 100 dislodged juvenile and 400 adult polyps of E. larynx per cubic meter of water were encountered in the immediate vicinity of an active net cleaning rig, while none were encountered prior to cleaning (Carl et al. 2011). Recent challenge trials in Ireland suggest that 'shredded' fragments of E. larynx arising during net cleaning might have the ability to cause pathological levels of gill irritation and damage in farmed Atlantic salmon (Baxter et al. 2012). The authors' personal observations of dense clouds of debris inside farm pens during net cleaning, and anecdotal accounts from Norwegian and Tasmanian farms of temporal behavioural changes in salmon following net cleaning (darting, jumping, agitation), imply considerable levels of exposure and, potentially, discomfort. In New Zealand, contact with fragments and defensive acontia of the white-striped anemone $A$. albocincta has been shown to cause sublethal and lethal skin ulceration in farmed Chinook salmon (Wybourne 2014). In 2013, up to $60 \%$ of fish in affected farm pens had skin lesions. While nematocysts were suspected agents of skin damage, secondary bacterial infections were thought to play an important role in ensuing pathologies and mortalities (B. Wybourne, Skretting, pers. comm.). This is consistent with recent observations of secondary bacterial infections (tenacibaculosis) following gill damage caused by jellyfish in Scotland (Ferguson et al. 2010).

In addition to being potential agents of gill and skin disorder, biofouling organisms can also act as hosts for aquatic pathogens. For example, fouling bivalves were identified decades ago as potential reservoirs of viral finfish pathogens (Meyers 1984). In 2014, a Norwegian project investigating potential reservoirs of Neoparamoeba perurans, the causal agent for amoebic gill disease (AGD), identified the amoeba in filterfeeding biofouling organisms such as mussels and hydroids collected from the net pens of a farm with acute AGD outbreak (A. Hellebø, Møreforskning, pers. comm.). Similarly, in 2013, E. larynx hydroids collected from a salmon farm in Ireland for molecular pathogen screening tested positive for the presence of $N$. perurans (H. Rodger, Vet-Aqua International, pers. comm.). Biofouling organisms from aquaculture facilities have also been shown to act as reservoirs or intermediate hosts of a range of aquaculture diseases such as net pen liver disease, hematopoietic necrosis and several others (Kumagai et al. 2011, Fitridge et al. 2012 and references therein). Depending on the geographic locality of fish farms, waste material released during net cleaning might thus contain potentially hazardous pathogens. There have also been suspicions that densities of salmon lice within net pens could be affected by the presence of biofouling, either by biofouling organisms directly harbouring lice (or their larvae) or by indirectly concentrating them within pens through the obstruction of water flows via net occlusion (Costelloe et al. 1996, Woll et al. 2014).

The disease risks described above may not only apply to the fish contained in the pen that is being cleaned, but potentially also to locations at some distance (Morrisey et al. 2011). No studies have yet quantified the sinking and dispersal behaviour of biofouling waste from net cleaning operations. There is likely to be considerable variation in sinking velocities between hard- and soft-bodied organisms, and consequently, the distance over which dispersion and deposition can occur. Deposition studies for commercial ship yards and dry-docks indicate that sinking rates of small biofouling fragments - in stagnant conditions - are low, and range from a few $\mathrm{mm}$ to a few $\mathrm{cm} \mathrm{min}^{-1}$ (Woods et al. 2007). Cnidarian nematocysts associated with detached or fragmented biofouling material can likely remain viable for several days (P. Schuchert, Geneva Museum of Natural History, pers. comm.). Similarly, pathogens and parasites associated with biofouling organisms may remain viable for some time following detachment from the pen nets. Depending on local current regimes, cleaning waste from fish farms may thus become transported, and pose disease risks to adjacent or regional aquaculture facilities. This material could also pose a potential threat to wild fish populations, such as wild Atlantic salmon migrating through Norwegian farming regions, or the substantial numbers of fish that accumulate around the physical structure provided by aquaculture installations (Dempster et al. 2004).

\section{Deposition and pollution risks}

The benthic footprint of farming operations is a key focus of studies on the environmental impacts of finfish aquaculture. Suspended pen farming of salmon is associated with a nearly continuous emission of non-ingested feed material and fish faeces that leave production pens and become deposited on the seabed surrounding the farms (Karakassis et al. 2002, Valdemarsen et al. 2012, Wang et al. 2012). Emissions vary in space and time, but for Atlantic salmon it is estimated that lost feed may approximate $5 \%$ of the total amount delivered, while annual loss of faecal material is estimated at $\sim 11$ to $13 \%$ of salmon bio- 
mass in a farm (Kutti 2008, Torrissen et al. 2011). Combined feed and faecal emissions from Norwegian salmon farms alone are thought to total $\sim 245000 \mathrm{t} \mathrm{yr}^{-1}$, or 350 to $400 \mathrm{t} \mathrm{farm}^{-1}$ annually (Taranger et al. 2013, Bannister et al. 2014). Depending on currents, particulate feed and faecal matter arising from fish farms can be deposited over distances of up to $\sim 1 \mathrm{~km}$ and may interfere with natural biogeochemical and trophic processes (Kutti et al. 2007, Valdemarsen et al. 2012, Callier et al. 2013).

To date, pen net cleaning has not been thoroughly considered in reviews, calculations or tracing of salmon farm emissions, despite the fact that, for many farms, the quantity of cleaning waste may not be insignificant in comparison to annual feed and faecal emissions (Table 1) (Brooks et al. 2002, Brooks \& Mahnken 2003, Holmer 2010). While standards and monitoring of benthic organic loading around farms involves assessments of total depositions (i.e. including any biofouling material), the development of effective mitigation measures would benefit from an understanding of the relative proportion of feed/ faecal and biofouling derived depositions. To our knowledge, Canada and Chile are one of few salmon growing regions where in situ net cleaning is subject to regulations. For example, in the Canadian provinces of New Brunswick and Nova Scotia, cleaning is restricted to 'lightly fouled' nets, while 'heavily fouled' nets are required to be cleaned in land-based facilities. However, no specific levels of fouling are defined, and compliance is only assessed indirectly through monitoring of the sea floor below the farm (B. House, Atlantic Canada Fish Farmers Association, pers. comm.). In Chile, cleaning of coppercoated nets at sea is prohibited and has to be carried out in land-based facilities where effluents can be treated (J. Unibazo, AVS, pers. comm.). In the scientific literature, biofouling material released from salmon farms is missing from dispersal and deposition models (Cromey et al. 2002, Stigebrandt et al. 2004, Bannister et al. 2016) although it is likely to behave very differently from feed and faecal emissions and possibly disperse further due to its lower sinking velocity (biofouling waste: $\mathrm{mm}$ to $\mathrm{cm} \mathrm{min}^{-1}$; feed and faeces: 8 to $16 \mathrm{~cm} \mathrm{~s}^{-1}$; Woods et al. 2007, Holmer 2010). We suspect that, where suspended pen farming is shown to result in benthic impacts stemming from farm-derived organic input, these impacts cannot always be fully mitigated by solely focusing on reducing feed and faecal emissions.

Where antifouling-coated nets are used, waste arising from high-pressure net cleaning is also likely to contain antifouling coating material. Antifouling coatings used in salmon aquaculture farms generally incorporate copper as their primary biocide (Braithwaite et al. 2007, Guenther et al. 2009, Guardiola et al. 2012). Copper is toxic to many marine organisms and therefore effective as an antifouling component. However, it can simultaneously harm non-target organisms; in fish, this can result in reduced swimming speed, molt delay, decreased embryonic development, reduced germination, reduced growth, changes in enzymatic activity and damaged gill filaments (reviewed in Burridge et al. 2010). In general, copper levels in cultured fish are found to be inconspicuous (Børufsen Solberg et al. 2002, Burridge et al. 2010), yet elevated levels have been measured in e.g. liver and muscle tissue of sea bass (Nikolaou et al. 2014). Sediments below sea farms can accumulate elevated copper levels (Loucks et al. 2012, Nikolaou et al. 2014), but the toxicity of the deposited copper is difficult to assess as it depends on the interaction with the environment where organic carbons and sulfides are able to reduce the reactivity (Burridge et al. 2010).

In 2013, 1016 t of copper were used to produce antifouling coatings for net pens in Norwegian salmon farms alone (Norwegian Ministry of Climate and Environment 2014), indicating an annual use of $\sim 1.5 \mathrm{t}$ of copper $\mathrm{farm}^{-1}$. Because some Norwegian farms do not use antifouling-treated nets, this figure is likely an underestimate for many farms that do. In Norway, the unauthorised release of hazardous chemicals into the environment is regulated and prohibited. However, although the release of copper and other hazardous chemicals from land-based net cleaning and recycling facilities is forbidden, these restrictions do not apply for in situ cleaning of nets at sea (Norwegian Ministry of Climate and Environment 2004). At individual salmon farms, the release of copper into the environment is controlled only indirectly through monitoring of copper levels in sediments below and around farms carried out during routine compliance monitoring of active salmon farms (Norwegian Ministry of Climate and Environment 2010, Standard Norge 2016). The majority of farms has copper levels below the threshold for environmental concern. However, of 279 farms whose sediment below the cages were monitored between 2011 and 2015, 20\% had copper concentrations considered toxic to marine life even during shortterm exposure (>84 $\mathrm{mg} \mathrm{Cu} \mathrm{kg}^{-1}$ dry weight sediment) (Svåsand et al. 2016). Salmon farmers and cleaning operators report considerable discolouration of water (matching the colour of the antifouling used) adjacent to cleaning rigs, particularly in the 
case of relatively recent coatings. Antifouling coating manufacturers themselves are concerned that highpressure cleaning can considerably erode their coatings and compromise their performance and longevity (V. Ohnstad Jr., Brynsløkken; B. Harvardsson, Steen Hansen, pers. comm.). For the same reason, inwater and land-based hull cleaning of marine vessels is increasingly subject to strict controls (Commonwealth Government of Australia 2013a). The composition, toxicity and degradation of antifouling coating fragments generated during high-pressure net cleaning may differ from that of benthic accumulations of biocides emitted via controlled leaching. Antifouling coating fragments abraded from nets could be relatively large (mm in diameter) and continue to leach biocides for some time following their deposition on the sea floor, leading to gradual increases in interstitial concentrations of contaminants. Coating fragments may also contain secondary ('booster') biocides that are often used to increase the effectiveness of copper-based antifouling coatings (Turner 2010). However, the deposition of antifouling biocides around fish farms, in particular compounds other than copper, is currently not well understood, and neither are their impacts on farmed fish, local species assemblages and sediment chemistry (Russell et al. 2011, Guardiola et al. 2012, Taranger et al. 2013, Nikolaou et al. 2014).

\section{Invasive species risk}

Many non-indigenous species have a high affinity for artificial substrates (Glasby et al. 2007). Aquaculture facilities often consist entirely of artificial surfaces - for example, an average Norwegian salmon farm comprises $\sim 50000 \mathrm{~m}^{2}$ of submerged artificial substrates (including nets, floating collars, mooring systems, feed systems, accommodation/feed barges and cleaner fish shelters) that represent potential settlement space for biofouling organisms (Bloecher et al. 2015). A large number of fish and mussel farms in North America, Europe and New Zealand support extensive populations of invasive species, such as the ascidians Styela clava, Ciona intestinalis and Didemnum vexillum, the amphipod Caprella mutica or the kelp Undaria pinnatifida (Raymont 1980, Ashton et al. 2007, Forrest et al. 2007, 2013, Ramsay et al. 2008). In situ cleaning of fouled net pens colonised by adult or mature biofouling organisms may inadvertently support the persistence and distribution of such species within aquaculture regions (Fig. 1). High-pressure cleaning is unlikely to effectively kill all organ- isms removed from the nets. During a study on the biosecurity risks associated with mechanical cleaning of ships' hulls Woods et al. (2007) examined 19000 organisms removed from 37 vessels. Overall, 13 to $48 \%$ of organisms within different fouling taxa were found to be alive and potentially viable following high-pressure cleaning. Particularly high survival rates were observed in mobile crustaceans (e.g. amhipods and skeleton shrimps), bivalves and ascidians - all of which are abundant biofouling taxa on finfish farming nets (Ashton et al. 2007, Braithwaite et al. 2007, Bloecher et al. 2013b). Carl et al. (2011) encountered large numbers of detached hydroid polyps in cleaning waste emissions and experimentally demonstrated that severed polyps were able to release several larvae over a $24 \mathrm{~h}$ period. Viable organisms, fragments and larvae released during cleaning events might sink below farm sites or drift to nearby natural habitats where some of them may recruit and establish. Damage or fragmentation of organisms during cleaning may also result in the release of viable gametes (eggs and sperm) if cleaning is undertaken at intervals that allow organisms to mature. If cleaning causes the synchronous release of gametes from a large number of organisms this could result in high encounter probabilities and, consequently, fertilisation rates (Inglis \& Gust 2003). In situ net cleaning may facilitate the spread of non-indigenous species established on aquaculture farms not only to surrounding natural habitats but also to neighbouring farms, thereby contributing to 'connectivity' between farms and the potential for stepping-stone invasions (Floerl et al. 2009, Inglis et al. 2013). Analogous to the risk associated with 'dispersion areas' within farming regions for the spread of aquatic diseases (Morrisey et al. 2011), drift of viable cleaning waste can potentially facilitate the spread of invasive biofouling species through high-density farming regions.

In situ cleaning of fish production pens is analogous to in situ cleaning of ships' hulls, a practice that has long been associated with a potential for releasing and spreading marine non-indigenous species and that is being carefully managed in some countries including Australia and New Zealand (Commonwealth Government of Australia 2013a, Morrisey et al. 2013). Because of concerns over the spread of invasive species through fish and mussel farming activities, the Australian government has recently released voluntary national biofouling management guidelines for the aquaculture industry (Commonwealth Government of Australia 2013b). While this document does not specifically deal with the regular practice of in situ net cleaning, it does highlight the 
potential for facilitating the spread of invasive species when undertaking high-pressure cleaning treatments of other farming infrastructure for biosecurity purposes.

\section{Exacerbated biofouling rates}

The release of viable gametes, larvae or spores of biofouling species as well as fragments of colonial organisms during in situ net cleaning may not only pose a risk with regard to the spread of invasive species, but may also facilitate elevated recruitment of biofouling organisms on surrounding farm surfaces ('self-seeding') or downstream farms, ironically leading to an increased need for cleaning activities (Fig. 1). For example, the larvae released by many hydroid species are readily able to settle to suitable substrates. Similarly, the larvae of many bryzoans and ascidians have short planktonic phases (Gili \& Hughes 1995, Floerl et al. 2010, Bloecher et al. 2013a). The release of large pulses of viable larvae during net cleaning operations could result in prompt recolonisation of recently cleaned, adjacent production pens, or accelerated biofouling development on other submerged farm surfaces such as floating collars, feed tubes, moorings and feed barges (Carl et al. 2011). During recent experiments in Norway conducted during the peak season for biofouling growth and net cleaning operations, recruitment rates of sessile species (particularly hydroids) in salmon farms were found to be orders of magnitude higher than in natural reference locations (Bloecher et al. 2015). The experimental identification of causal factors for these observed patterns is ongoing, but one potential explanation is that the extensive, and largely un-managed, resident populations on submerged farm infrastructure other than pen nets act as reservoirs of biofouling propagules (Guenther et al. 2010).

Exacerbated biofouling rates can also be caused by the re-attachment and regeneration of fragments of clonal biofouling organisms dislodged and physically damaged during net cleaning. For example, experiments with fragments of colonial bryozoans and ascidians have shown that re-attachment rates can be as high as $100 \%$, dependent on species, fragment size and environmental conditions (Bullard et al. 2007, Hopkins et al. 2011), and similar concerns have been raised for E. larynx (Carl et al. 2011). For some ascidians, re-attachment is still possible after $4 \mathrm{wk}$ in suspension (Morris \& Carman 2012) and the fouling cover on vacant target surfaces can be greater due to colonisation by fragments than from larval recruit- ment (Forrest et al. 2013). Fragmentation of colonial fouling species through high-pressure cleaning could exacerbate biofouling rates in adjacent coastal environments.

\section{RESEARCH NEEDS}

The sections above describe the potential environmental risks associated with current biofouling management practices in global salmon aquaculture. Carefully designed studies and R \& D initiatives are now required to fully understand and quantify these risks and to support the development of mitigation tools where appropriate. A summarised agenda for relevant research priorities is provided in Table 2. Of particular importance and wide-ranging benefit are studies that measure the concentration and composition of biofouling waste arising in different cleaning situations, the effects of this material on health and welfare of farmed fish and the dispersal and deposition of cleaning waste to surrounding farms and benthic natural habitats (Table 2). An improved understanding of the association of aquaculture pathogens with biofouling organisms will enable farm operators to better manage the risk of disease outbreaks.

A further priority area is the development of enhanced net cleaning technologies that are able to capture and collect biofouling material removed from farm surfaces (analogous developments are being made internationally for ship-hull cleaning; Lewis 2013). The availability of such technologies, once proven effective, could help mitigate the potential environmental risks discussed in this article (e.g. impacts from nematocyst exposure or benthic deposition of cleaning waste; Fig. 1), and open new research avenues for the commercial utilisation of biofouling material from aquaculture operations (e.g. as fertiliser, as nutritional supplements in fish feed, to generate bio-energy, etc.). While new technology is being developed, there may be merit in improving net cleaning tactics so cleaning operations can reliably prevent the release of viable organisms or reproductive propagules. There is also a great need for improved, environmentally sustainable antifouling technologies that reduce biofouling loads on individual farms and the frequency at which in situ net cleaning is required. As illustrated in Table 1, reducing the fouling biomass on production net pens and/or the need for frequent cleaning of nets can yield substantial reductions in the annual amount of biofouling waste arising from salmon farms - and thereby in the environmental risks discussed in this 
Table 2. Research and development priorities to understand, quantify and mitigate different types of environmental risk associated with biofouling management in salmon aquaculture: health or disease risks (HDR); deposition or pollution risks (DPR); invasive species risks (IR) and exacerbated biofouling risk (EB)

\begin{tabular}{|c|c|c|}
\hline $\mathrm{R} \& \mathrm{D}$ priority & Insights and outcomes & $\begin{array}{l}\text { Addresses } \\
\text { risk types }\end{array}$ \\
\hline \multicolumn{3}{|l|}{ Understanding risk } \\
\hline $\begin{array}{l}\text { Quantify in situ concentrations, composition, } \\
\text { sinking rates and dispersal of biofouling cleaning } \\
\text { waste }\end{array}$ & $\begin{array}{l}\text { Exposure patterns to farmed fish, creation of contact } \\
\text { networks with adjacent/regional farms and natural } \\
\text { habitats, contribution to benthic footprint }\end{array}$ & $\begin{array}{l}\text { HDR, DPR, } \\
\text { IR, EB }\end{array}$ \\
\hline $\begin{array}{l}\text { Determine rate of survival and re-attachment of } \\
\text { larvae, fragments and adult organisms contained } \\
\text { within cleaning waste }\end{array}$ & $\begin{array}{l}\text { Ability of organisms in cleaning waste to survive and } \\
\text { colonise adjacent structures or habitats }\end{array}$ & IR, EB \\
\hline $\begin{array}{l}\text { Determine effects of cnidarian nematocysts on gill } \\
\text { and skin tissues and potential facilitative effects for } \\
\text { infectious diseases }\end{array}$ & $\begin{array}{l}\text { Role of biofouling as a risk factor for gill disorder and } \\
\text { gill disease in marine aquaculture }\end{array}$ & HDR \\
\hline $\begin{array}{l}\text { Better determine association of biofouling organ- } \\
\text { isms with aquaculture disease pathogens }\end{array}$ & $\begin{array}{l}\text { Source and reservoir effects of biofouling communities } \\
\text { for aquaculture pathogens }\end{array}$ & HDR, IR \\
\hline $\begin{array}{l}\text { Include biofouling cleaning emissions in farm } \\
\text { dispersion and deposition models }\end{array}$ & $\begin{array}{l}\text { Support for understanding existing impacts, siting of } \\
\text { new facilities and area/zone-based management }\end{array}$ & $\begin{array}{l}\text { HDR, DPR, } \\
\quad \text { IR }\end{array}$ \\
\hline $\begin{array}{l}\text { Collect data on current industry practices for } \\
\text { managing biofouling and their success }\end{array}$ & $\begin{array}{l}\text { Improved understanding of industry practices and } \\
\text { effective targeting of future research }\end{array}$ & $\begin{array}{l}\text { HDR, DPR, } \\
\text { IR, EB }\end{array}$ \\
\hline \multicolumn{3}{|l|}{ Managing risk } \\
\hline $\begin{array}{l}\text { Improved antifouling solutions, where appropriate } \\
\text { to harmonise with net cleaning technology }\end{array}$ & $\begin{array}{l}\text { Reduced need for in situ cleaning and reduced cleaning } \\
\text { biomass, reduced biofouling maintenance costs }\end{array}$ & $\begin{array}{l}\text { HDR, DPR, } \\
\text { IR, EB }\end{array}$ \\
\hline $\begin{array}{l}\text { Development of standardised monitoring tools and } \\
\text { units of measurement for biofouling }\end{array}$ & $\begin{array}{l}\text { Increased ability to quantify biofouling patterns and } \\
\text { make comparisons between growing regions }\end{array}$ & $\begin{array}{l}\text { HDR, DPR, } \\
\quad \text { IR, EB }\end{array}$ \\
\hline $\begin{array}{l}\text { Development and evaluation of cleaning tools that } \\
\text { capture and retain biofouling cleaning waste }\end{array}$ & $\begin{array}{l}\text { Effective mitigation of all potential risks described here; } \\
\text { ability to utilise waste material }\end{array}$ & $\begin{array}{l}\text { HDR, DPR, } \\
\text { IR, EB }\end{array}$ \\
\hline $\begin{array}{l}\text { Best-practice industry guidelines for cleaning of } \\
\text { nets and other submerged surfaces }\end{array}$ & $\begin{array}{l}\text { Increased industry awareness, adoption of standardised } \\
\text { practices and mitigation strategies across the industry }\end{array}$ & $\begin{array}{l}\mathrm{HDR}, \mathrm{DPR}, \\
\text { IR, EB }\end{array}$ \\
\hline
\end{tabular}

article. Of particular importance is the 'harmonisation' of cleaning and antifouling technologies, if both are to be used together. The most effective antifouling coatings are of limited value if they are degraded and removed from the net by the use of high-pressure jets or other abrasive cleaning methods. Developing cleaning tools that support or enhance antifouling performance (where used) will enable more cost-effective biofouling management and, ideally, reduce emissions of biocidal material and cleaning waste. The Aquaculture Stewardship Council (ASC) Salmon Standard (ASC 2012) could be an important driving factor for the improvement of current biofouling maintenance concepts. By banning in situ highpressure cleaning of nets with copper-based antifouling coatings, the standard will force salmon companies to either forego antifouling coatings or invest into the development of alternative, more acceptable cleaning technologies. Seventeen global salmon companies comprising $70 \%$ of the world's salmon production have committed to achieving full ASC certification by 2020 (ASC 2015). This should represent a strong incentive for technology developers to find alternative solutions for both coatings and net cleaning equipment.

The R \& D priorities listed in Table 2 go far beyond the realm of biofouling ecology and will require multi-disciplinary research spanning biology, hydrological modelling, veterinary science, ecotoxicology and engineering. The results can be used to develop novel tools as well as science-based industry codes of practice and guidelines that can ensure the effective uptake of sustainable, low-risk approaches to biofouling management in aquaculture. 


\section{CONCLUSIONS}

This article discusses the potential environmental risks associated with current biofouling management in salmon aquaculture, principally in-water cleaning - a practice that has so far been largely left unregulated and has not received much scientific attention. Addressing some of the key knowledge gaps described in the sections above could provide both short- and long-term benefits to the fish farming industry with regard to farming operations, fish health, environmental sustainability, public image and, ultimately, profitability. The introduction of guidelines and regulations regarding biofouling management might be met with skepticism from industry, but could provide economic incentives for the development and availability of improved, low-risk technologies and practices, and ultimately result in economic gains via an improved license to operate. Any guidelines or regulations, as well as the development and uptake of improved management technologies, should be underpinned by adequate scientific experiments and evaluations. Best results are likely to be achieved via strong collaboration between scientists and the aquaculture industry.

Acknowledgements. We thank Javier Atalah (Cawthron Institute), Betty House (Atlantic Canada Fish Farmers Association), Diane Morris (Marine Harvest Canada), Steve Percival (Huon Aquaculture), Hamish Rodger (Vet-Aqua International), Javier Unibazo (AVS Chile), Ben Wybourne (Skretting), and Belinda Yaxley (Petuna Aquaculture) for providing information and data for aspects of this article, and Lars Gansel for helpful discussions on this subject. Audny Hellebø (Møreforskning) kindly provided data from the FHF project 901003 'Undersøking av potensielle reservoirer for Paramoeba perurans på marine oppdrettslokaliteter for atlantisk laks'. Thanks are also due to Javier Atalah and 3 anonymous reviewers for providing comments on an earlier version of the manuscript.

\section{LITERATURE CITED}

ASC (Aquaculture Stewardship Council) (2012) ASC salmon standard version 1.0. Aquaculture Stewardship Council, Utrecht

ASC (2015) ASC helps salmon aquaculture towards sustainability goal. www.asc-aqua.org/index.cfm?act=update. detail\&uid=270\&lng=1 (accessed 21 Oct 2015)

Ashton GV, Willis KJ, Cook EJ, Burrows M (2007) Distribution of the introduced amphipod, Caprella mutica Schurin, 1935 (Amphipoda: Caprellida: Caprellidae) on the west coast of Scotland and a review of its global distribution. Hydrobiologia 590:31-41

Atalah J, Smith KF (2015) Assessment of stinging cells and identity of anemones at Ruakaka Bay salmon farm. Cawthron Institute Report No. 2672. Cawthron Institute, Nelson
Atalah J, Newcombe E, Hopkins G (2013) Biofouling community composition at three salmon farms in Queen Charlotte Sound. Cawthron Institute Report No. 14. Cawthron Institute, Nelson

> Bannister RJ, Valdemarsen T, Hansen PK, Holmer M, Ervik A (2014) Changes in benthic sediment conditions under an Atlantic salmon farm at a deep, well-flushed coastal site. Aquacult Environ Interact 5:29-47

Bannister RJ, Johnsen IA, Hansen PK, Kutti T, Asplin L (2016) Near- and far-field dispersal modelling of organic waste from Atlantic salmon aquaculture in fjord systems. ICES J Mar Sci, doi:10.1093/icesjms/fsw027

Baxter EJ, Sturt MM, Ruane NM, Doyle TK, McAllen R, Harman L, Rodger HD (2011) Gill damage to Atlantic salmon (Salmo salar) caused by the common jellyfish (Aurelia aurita) under experimental challenge. PLoS ONE 6:e18529

Baxter EJ, Sturt MM, Ruane NM, Doyle TK, McAllen R, Rodger HD (2012) Biofouling of the hydroid Ectopleura larynx on aquaculture nets in Ireland: implications for finfish health. Fish Vet J 13:17-29

Bloecher N (2013) Biofouling in the Norwegian salmon farming industry. PhD thesis, Norwegian University of Science and Technology, Trondheim

Bloecher N, de Nys R, Poole AJ, Guenther J (2013a) The fouling hydroid Ectopleura larynx: a lack of effect of next generation antifouling technologies. Biofouling 29:237-246

> Bloecher N, Olsen Y, Guenther J (2013b) Variability of biofouling communities on fish cage nets: A 1-year field study at a Norwegian salmon farm. Aquaculture 416-417: 302-309

> Bloecher N, Floerl O, Sunde LM (2015) Amplified recruitment pressure of biofouling organisms in commercial salmon farms: potential causes and implications for farm management. Biofouling 31:163-172

Børufsen Solberg C, Sæthre L, Julshamn K (2002) The effect of copper-treated net pens on farmed salmon (Salmo salar) and other marine organisms and sediments. Mar Pollut Bull 45:126-132

> Braithwaite RA, McEvoy LA (2005) Marine biofouling on fish farms and its remediation. Adv Mar Biol 47:215-252

Braithwaite RA, Carrascosa MCC, McEvoy LA (2007) Biofouling of salmon cage netting and the efficacy of a typical copper-based antifoulant. Aquaculture 262:219-226

> Brooks KM, Mahnken CVW (2003) Interactions of Atlantic salmon in the Pacific northwest environment: II. Organic wastes. Fish Res 62:255-293

Brooks KM, Mahnken C, Nash C (2002) Environmental effects associated with marine netpen waste with emphasis on salmon farming in the Pacific northwest. In: Stickney RR, McVey JP (eds) Responsible marine aquaculture. CABI Publishing, New York, NY, p 159-204

> Bullard SG, Sedlack B, Reinhardt JF, Litty C, Gareau K, Whitlatch RB (2007) Fragmentation of colonial ascidians: differences in reattachment capability among species. J Exp Mar Biol Ecol 342:166-168

Burridge L, Weis JS, Cabello F, Pizarro J, Bostick K (2010) Chemical use in salmon aquaculture: a review of current practices and possible environmental effects. Aquaculture 306:7-23

> Callier MD, Lefebvre S, Dunagan MK, Bataille MP, Coughlan J, Crowe TP (2013) Shift in benthic assemblages and organisms' diet at salmon farms: community structure and stable isotope analyses. Mar Ecol Prog Ser 483:153-167

- Carl C, Guenther J, Sunde LM (2011) Larval release and 
attachment modes of the hydroid Ectopleura larynx on aquaculture nets in Norway. Aquacult Res 42:1056-1060

Cegolon L, Heymann WC, Lange JH, Mastrangelo G (2013) Jellyfish stings and their management: a review. Mar Drugs 11:523-550

Commonwealth Government of Australia (2013a) Anti-fouling and in-water cleaning guidelines. Department of Agriculture, Fisheries and Forestry, Department of Sustainability, Environment, Water, Population and Communities, and New Zealand Ministry for Primary Industries, Canberra

Commonwealth Government of Australia (2013b) National biofouling management guidance for the aquaculture industry. Commonwealth Government of Australia, Canberra

Costelloe M, Costelloe J, Roche N (1996) Planktonic dispersion of larval salmon-lice, Lepeophtheirus salmonis, associated with cultured salmon, Salmo salar, in western Ireland. J Mar Biol Assoc UK 76:141-149

> Cromey C, Nickell T, Black K, Provost P, Griffiths C (2002) Validation of a fish farm waste resuspension model by use of a particulate tracer discharged from a point source in a coastal environment. Estuaries 25:916-929

Cronin ER, Cheshire AC, Clarke SM, Melville AJ (1999) An investigation into the composition, biomass and oxygen budget of the fouling community on a tuna aquaculture farm. Biofouling 13:279-299

> Daigle RM, Herbinger CM (2009) Ecological interactions between the vase tunicate (Ciona intestinalis) and the farmed blue mussel (Mytulis edulis) in Nova Scotia, Canada. Aquat Invasions 4:177-187

> Dempster T, Sanchez-Jerez P, Bayle-Sempere J, Kingsford M (2004) Extensive aggregations of wild fish at coastal sea-cage fish farms. Hydrobiologia 525:245-248

Ferguson HW, Christian MD, Hay S, Nicolson J, Sutherland D, Crumlish M (2010) Jellyfish as vectors of bacterial disease for farmed salmon (Salmo salar). J Vet Diagn Invest 22:376-382

Fitridge I, Dempster T, Guenther J, de Nys R (2012) The impact and control of biofouling in marine aquaculture: a review. Biofouling 28:649-669

Floerl O, Inglis G, Dey KL, Smith A (2009) The importance of transport hubs in stepping-stone invasions. J Appl Ecol 46:37-45

Floerl O, Wilkens S, Woods C (2010) Temporal development of biofouling assemblages. NIWA Client Report CHC2012-103, prepared for the Department of Agriculture, Fisheries and Forestry. National Institute of Water \& Atmospheric Research, Christchurch

Forrest BM, Hopkins GA, Dodgshun TJ, Gardner JPA (2007) Efficacy of acetic acid treatments in the management of marine biofouling. Aquaculture 262:319-332

Forrest BM, Fletcher LM, Atalah J, Piola RF, Hopkins GA (2013) Predation limits spread of Didemnum vexillum into natural habitats from refuges on anthropogenic structures. PLoS ONE 8:e82229

Frazão B, Vasconcelos V, Antunes A (2012) Sea anemone (Cnidaria, Anthozoa, Actiniaria) toxins: an overview. Mar Drugs 10:1812-1851

Gili JM, Hughes RG (1995) The ecology of marine benthic hydroids. Oceanogr Mar Biol Annu Rev 33:351-426

Glasby T, Connell S, Holloway M, Hewitt C (2007) Nonindigenous biota on artificial structures: Could habitat creation facilitate biological invasions? Mar Biol 151:887-895

Greene JK, Grizzle RE (2007) Successional development of fouling communities on open ocean aquaculture fish cages in the western Gulf of Maine, USA. Aquaculture 262:289-301

Guardiola FA, Cuesta A, Meseguer J, Esteban MA (2012) Risks of using antifouling biocides in aquaculture. Int $\mathrm{J}$ Mol Sci 13:1541-1560

> Guenther J, Carl C, Sunde LM (2009) The effects of colour and copper on the settlement of the hydroid Ectopleura larynx on aquaculture nets in Norway. Aquaculture 292: 252-255

Guenther J, Misimi E, Sunde LM (2010) The development of biofouling, particularly the hydroid Ectopleura larynx, on commercial salmon cage nets in Mid-Norway. Aquaculture 300:120-127

> Guenther J, Fitridge I, Misimi E (2011) Potential antifouling strategies for marine finfish aquaculture: the effects of physical and chemical treatments on the settlement and survival of the hydroid Ectopleura larynx. Biofouling 27: 1033-1042

Hargrave BT (2010) Empirical relationships describing benthic impacts of salmon aquaculture. Aquacult Environ Interact 1:33-46

Holmer M (2010) Environmental issues of fish farming in offshore waters: perspectives, concerns and research needs. Aquacult Environ Interact 1:57-70

Hopkins GA, Forrest BM, Piola RF, Gardner JPA (2011) Factors affecting survivorship of defouled communities and the effect of fragmentation on establishment success. J Exp Mar Biol Ecol 396:233-243

Inglis GJ, Gust N (2003) Potential indirect effects of shellfish culture on the reproductive success of benthic predators. J Appl Ecol 40:1077-1089

Inglis G, Morrisey D, Woods C, Sinner J, Newton M (2013) Managing the domestic spread of harmful marine organisms. Part A: Operational tools for management. NIWA Client Report CHC2013-150, prepared for the Ministry for Primary Industries. National Institute of Water \& Atmospheric Research, Christchurch

Karakassis I, Tsapakis M, Smith CJ, Rumohr H (2002) Fish farming impacts in the Mediterranean studied through sediment profiling imagery. Mar Ecol Prog Ser 227: $125-133$

Kumagai A, Suto A, Ito H, Tanabe T and others (2011) Soft tunic syndrome in the edible ascidian Halocynthia roretzi is caused by a kinetoplastid protist. Dis Aquat Org 95: 153-161

Kutti T (2008) Regional impact of organic loading from a salmonid farm: dispersal, sedimentation rates and benthic fauna response. PhD thesis, University of Bergen

Kutti T, Ervik A, Hansen PK (2007) Effects of organic effluents from a salmon farm on a fjord system. I. Vertical export and dispersal processes. Aquaculture 262:367-381

Kvenseth PG (1996) Large-scale use of wrasse to control sea lice and net fouling in salmon farms in Norway. In: Sayer MDJ, Treasurer JW, Costello MJ (eds) Wrasse: biology and use in aquaculture. Wiley-Blackwell, Cambridge

Lader P, Dempster T, Fredheim A, Jensen Ø (2008) Current induced net deformations in full-scale sea-cages for Atlantic salmon (Salmo salar). Aquacult Eng 38:52-65

Lader P, Fredriksson D, Guenther J, Volent Z and others (2015) Drag on hydroid-fouled nets - an experimental approach. China Ocean Eng 29:369-389

LeBlanc AR, Landry T, Miron G (2003) Fouling organisms of the blue mussel Mytilus edulis: their effect on nutrient uptake and release. J Shellfish Res 22:633-638 
Lewis J (2013) In-water hull cleaning and filtration system: in-water cleaning trials. Fisheries Occasional Publication No. 114, Government of Western Australia Department of Fisheries, Perth

Loucks RH, Smith RE, Fisher CV, Fisher EB (2012) Copper in the sediment and sea surface microlayer near a fallowed, open-net fish farm. Mar Pollut Bull 64:1970-1973

Meyers TR (1984) Marine bivalve mollusks as reservoirs of viral finfish pathogens: significance to marine and anadromous finfish aquaculture. Mar Fish Rev 46:14-17

Morris J Jr, Carman M (2012) Fragment reattachment, reproductive status, and health indicators of the invasive colonial tunicate Didemnum vexillum with implications for dispersal. Biol Invasions 14:2133-2140

Morrisey D, Plew D, Seaward K (2011) Aquaculture readiness data: Phase II. NIWA Client Report, prepared for MAF Biosecurity New Zealand. National Institute of Water \& Atmospheric Research, Christchurch

Morrisey D, Gadd J, Page M, Floerl O and others (2013) Inwater cleaning of vessels: biosecurity and chemical contamination risks. Ministry for Primary Industries, Wellington

Nikolaou M, Neofitou N, Skordas K, Castritsi-Catharios I, Tziantziou L (2014) Fish farming and anti-fouling paints: a potential source of $\mathrm{Cu}$ and $\mathrm{Zn}$ in farmed fish. Aquacult Environ Interact 5:163-171

Norwegian Ministry of Climate and Environment (2004) Pollution Control Act (Forskrift om begrensning av forurensning - forurensningsforskriften; Del 7, Krav til forebygging av forurensning fra visse virksomheter eller utslippskilder; Kapittel 25, Forurensning fra vask og impregnering av oppdrettsnøter). Government of Norway, Oslo (in Norwegian)

Norwegian Ministry of Climate and Environment (2010) Prioritised environmental pollutants 2007: status and prognosis (Prioriterte miljøgifter i 2007: Status og utslippsprognoser). Government of Norway, Olso (in Norwegian)

Norwegian Ministry of Climate and Environment (2014) Copper and other chemicals in aquaculture (Kobber og andre kjemikalier i fiskeoppdrett). www.miljostatus.no/Tema/ Hav-og-kyst/Fiskeoppdrett/Kobber-og-andre-kjemikalieri-fiskeoppdrett/ (accessed 21 Oct 2015) (in Norwegian)

Olafsen T (2006) Cost analysis of different antifouling strategies (Kostnadsanalyse av ulike begroingshindrende strategier). SINTEF Fisheries and Aquaculture, Document No. SFH80 A066041, Trondheim (in Norwegian)

Ramsay A, Davidson J, Landry T, Arsenault G (2008) Process of invasiveness among exotic tunicates in Prince Edward Island, Canada. Biol Invasions 10:1311-1316

Raymont JGE (1980) Plankton and productivity in the oceans, 2nd edn. Vol 1: Phytoplankton. Pergamon Press, Oxford

Rensel JE, Forster JRM (2007) Beneficial environmental effects of marine finfish mariculture. NOAA National Marine Fisheries Service, Washington, DC

Rodger HD, Henry L, Mitchell SO (2011) Non-infectious gill disorders of marine salmonid fish. Rev Fish Biol Fish 21: $423-440$

Editorial responsibility: Gianluca Sara, Palermo, Italy
Russell M, Robinson CD, Walsham P, Webster L, Moffat CF (2011) Persistent organic pollutants and trace metals in sediments close to Scottish marine fish farms. Aquaculture 319:262-271

Sher D, Zlotkin E (2009) A hydra with many heads: protein and polypeptide toxins from hydra and their biological roles. Toxicon 54:1148-1161

Standard Norge (2016) Environmental monitoring of benthic impact from marine fish farms (Miljøovervåking av bunnpåvirkning fra marine akvakulturanlegg). Standard NS9410:2016 (in Norwegian)

> Stigebrandt A, Aure J, Ervik A, Hansen PK (2004) Regulating the local environmental impact of intensive marine fish farming: III. A model for estimation of the holding capacity in the Modelling-Ongrowing fish farm-Monitoring system. Aquaculture 234:239-261

Svåsand T, Karlsen Ø, Kvamme BO, Stien LH, Taranger GL, Boxaspen KK (2016) Risk assessment of Norwegian aquaculture (Risikovurdering norsk fiskeoppdrett 2016). Institute of Marine Research, Bergen (in Norwegian)

Taranger GL, Svåsand T, Kvamme BO, Kristiansen T, Boxaspen KK (2013) Risk assessment of Norwegian aquaculture (Risikovurdering norsk fiskeoppdrett 2012). Institute of Marine Research, Bergen (in Norwegian)

Taranger GL, Karlsen Ø, Bannister RJ, Glover KA and others (2015) Risk assessment of the environmental impact of Norwegian Atlantic salmon farming. ICES J Mar Sci 72: 997-1021

Torrissen O, Olsen RE, Toresen R, Hemre GI and others (2011) Atlantic salmon (Salmo salar): the 'super-chicken' of the sea? Rev Fish Sci 19:257-278

Turner A (2010) Marine pollution from antifouling paint particles. Mar Pollut Bull 60:159-171

Valdemarsen T, Bannister RJ, Hansen PK, Holmer M, Ervik A (2012) Biogeochemical malfunctioning in sediments beneath a deep-water fish farm. Environ Pollut 170: $15-25$

- Wang XX, Olsen LM, Reitan KI, Olsen Y (2012) Discharge of nutrient wastes from salmon farms: environmental effects, and potential for integrated multi-trophic aquaculture. Aquacult Environ Interact 2:267-283

Woll AK, Sandnes OK, Staven FR, Oslsen Y and others (2014) Environmental documentation Nordmøre (Miljødokumentasjon Nordmøre). Report prepared for FHL Havbruk, Ålesund (in Norwegian)

Woods C, Floerl O, Fitridge I, Johnston O and others (2007) Efficacy of hull cleaning operations in containing biological material. II. Seasonal variability. MAF Biosecurity New Zealand Technical Paper Series 08/11, Wellington

Woods CMC, Floerl O, Hayden BJ (2012) Biofouling on Greenshell ${ }^{\mathrm{TM}}$ mussel (Perna canaliculus) farms: a preliminary assessment and potential implications for sustainable aquaculture practices. Aquacult Int 20:537-557

Wybourne B (2014) Defensive acontia of the white-striped anomone (Actinothoe albocincta) from New Zealand King Salmon Clay Point salmon farm. Report prepared for NZ King Salmon Company. Skretting, Marlborough

Submitted: December 9, 2015; Accepted: June 9, 2016

Proofs received from author(s): July 14, 2016 